JUN-HYUK KIM, Ph.D.

E-mail: junhyuk@koti.re.kr

The Korea Transport Institute

315 Goyangdaero, Goyang-si, Gyeonggi-do, 411-701,

Republic of Korea

SOONHU SOH, Ph.D.

E-mail: soonhu@wku.ac.kr

Wonkwang University

Division of Business Administration

344-2 Sinyong-dong, Iksan, Jeonbuk, 570-749,

Republic of Korea
Traffic and Space

Preliminary Communication

Accepted: Oct. 25, 2011

Approved: Oct. 3, 2012

\title{
DESIGNING HUB-AND-SPOKE SCHOOL BUS TRANSPORTATION NETWORK: A CASE STUDY OF WONKWANG UNIVERSITY
}

\begin{abstract}
This paper provides a case study of hub-and-spoke school bus transportation network design. The case study here utilizes a mathematical model that is the P-median optimization model to determine optimal hub locations. The P-median problem is a combinatorial optimization problem that includes many binary variables and constraints. The selected objective of the model is to minimize the total travel time satisfying other operational constraints. To elevate usability of decision making in the future, we implement the simulation model through the template model in spreadsheet platform. The developed model is used as a future reference to find operational directions of school bus managing policy and also tested on the case of Wonkwang University.
\end{abstract}

\section{KEY WORDS}

hub-and-spoke network, school bus, P-median model, case study

\section{INTRODUCTION}

The hub-and-spoke network consists of a set of fully interconnected facilities called hubs among a potential set of locations, and spokes that directly connect the hubs [1, 2, 3]. The flow between spokes is maintained through hubs. This network structure achieves economies of scale by consolidating and rerouting shipments at hubs. Using consolidating scheme to the hubs, the hub-and-spoke network strategy enables to provide flexible transportation service even though the quantity of shipment from various origins is inconsistent and fluctuates [4]. Currently, a hub-and-spoke net- work is being widely used in airline, shipping, postal industries, and other communication systems [5, 6, 7].

In this paper, hub-and-spoke network strategy is applied to the school bus transportation network design problem through a case study. The problem addressed here deals with the designing of school bus transportation network to transport students who are widely dispersed from the school.

The majority of researches on the school bus planning are devoted to the school bus routing problem [8, $9,10,11]$. This problem is to determine an efficient plan or schedule for buses where each bus picks up students from dispersed bus stops and transports them to their designated school while satisfying various constraints $[12,13]$. A variety of operational objectives are considered in school bus routing problem in general. One is to minimize the overall operating cost. The others are to maximize customer service level by reducing waiting time, increasing seat availability, punctuality, and other goals related to customer satisfaction. The constraints depend on problem natures and include the bus capacity, the riding time limitation, the time window of schools, and there are other operational constraints that have to be considered. The comprehensive review of this problem has been provided in the literature [14].

In general, designing such a network is comprised of several sub-problems such as hub location problem, spoke allocation to designated hubs, and route planning between hubs and spokes. Among such problems, we focus on deciding the number of hubs, hub locations, and allocating spokes to hubs to mini- 
mize the total transportation cost. We take into account fixed bus stops as the spoke locations and the hub locations are therefore selected among the bus stops. The P-median problem (PMP) model is used to design the hub-and-spoke school bus transportation network. Furthermore, a decision-making system tool for network planning using Risk Solver provided from Frontline System has been developed to make decisions easier for planners.

The PMP is one of the representative location problems to find the location of $P$ facilities on a network so that the total cost is minimized [15]. The PMP and its extensions are beneficial to model many real world conditions, such as the location of plants, warehouses, and other public facilities $[16,17]$. The PMP is classified as NP(non-deterministic polynomial-time)-hard so that the instances of practical size cannot be solved within reasonable time. Many studies had been conducted for the PMP [18, 19, 20, 21, 22]. The solution approaches found in previous literature are broadly categorized into exact algorithms and heuristics. Due to the nature of complexity of the real world problems, various heuristic approaches are mainly proposed for the PMP. The reader is referred to the survey article [23].

This research aims to provide a hub-and-spoke school bus network design with various scenarios in real situation currently faced by the Wonkwang University, South Korea. The Wonkwang University is now operating 48 buses spending 1.8 million dollars per year to offer commuting service for about 4,500 students residing in two geographic regions. The average commuting time from each region to the school is approximately one hour. This fact means that the Wonkwang University has fairly wide geographic areas to cover and it makes operational planning and control more complicated. Due to a number of complaints and requests from the users, the Wonkwang University has initiated structural transforming of the current operation policy considering hub-and-spoke network strategy.

This paper is organized as follows. In Section 2, we describe the PMP model in detail. We then define the case study problem and provide a comprehensive analysis on the results obtained in Section 3, which is followed by conclusions in Section 4 .

\section{P-MEDIAN PROBLEM MODEL}

In general, the hub location in hub-and-spoke network is determined by modelling hub location problem in which the total transportation cost is minimized with the given demand between all origin and destination pairs. Due to a single destination (school, in this case), the hub location decision is accomplished by solving PMP. The PMP is a binary integer linear program model to decide on the optimal hub location minimizing the total distance travelled to hubs with the given constraints. The PMP is a type of the combinatorial optimization problem; thus, the computation time is extremely increased as the number of decision variables increase. The PMP is formulated as follows.

Minimize

$\sum_{i} \sum_{j} s_{i} d_{i j} Y_{i j}$

Subject to

$\sum Y_{i j}=1$

$Y_{i j}-X_{j} \leq 0 \quad \forall i, j$

$\sum_{j} X_{j}=P$

$X_{j}=0,1$

$\forall j$

$Y_{i, j}=0,1$

$\forall i, j$

where:

$s_{i}=$ demand at stop $i$

$d_{i, j}=$ distance between stop $i$ and potential hub location $j$

$P=$ number of hubs to locate

$X_{j}=\left\{\begin{array}{l}1, \text { if hub is located at potential hub location } j \\ 0, \text { otherwise }\end{array}\right.$

$Y_{i, j}=\left\{\begin{array}{l}1, \text { if demand at stop } i \text { is serviced by hub location } j \\ 0, \text { otherwise }\end{array}\right.$

The objective function (1) minimizes the total demand-weighted distance between each bus stop and hub. The constraint (2) ensures that each bus stop is clustered into exactly one hub. The constraint (3) describes the relationship between the location variable $\left(X_{j}\right)$ and the allocation variable $\left(Y_{i, j}\right)$. Equation (3) requires that demand at stop $i$ can only be assigned to a hub $j\left(Y_{i, j}=1\right)$ if a hub is located at stop $j\left(X_{i, j}=1\right)$. The constraint (4) guarantees that the $P$ number of hubs should be located. The constraints (5) and (6) represent that all variables must be binary.

\section{CASE STUDY OF THE WONKWANG UNIVERSITY}

\subsection{Case problem}

The Wonkwang University is currently operating 43 buses covering regions $A, B$, main study areas in this research, and 5 buses to other cities which make a total of 48 buses running 186 times a day. In Region A, there are 43 bus stops and about 3,003 students were commuting students in 2010 , at the same time, and 27 stops managed and about 1,411 students use the school bus service in Region B among a total of 4,414 students who use service currently at the Wonkwang University. Region A is a city located about $25 \mathrm{~km}$ to the west, and Region B is located about $27 \mathrm{~km}$ to 
the southeast of the University. Approximately, 1.8 million dollars in the annual budget have been spent on school bus management and 95\% of the budget was collected from the students in 2009. Thus, due to the high ratio of user expenses, high quality of service should be considered as one of the key priority.

At present, the major concern for promoting the service level is to increase seat availability. Many students who reside in Region A or B undergo standing commuting caused by seat unavailability. Resulting from recent observation on the service in spring semester, 2010, $5.6 \%$ of total daily services in Region $A$ and $9.1 \%$ in Region B exceeded the 45 seat capacity which found to be standing commuting. The standing commuting issue is the main motivation for the Wonkwang University to make an effort to improve the current school bus management system even though other operational objectives, such as saving operating cost, reducing commuting time should be achieved as well.

\subsection{Application and analysis}

The demand data and distance information between stops need to be collected to establish PMP in this study. The average daily demand information at each stop is acquired by processing raw data that is shown by the number of students counted in each boarding time at a single stop. The precise travel distance between stops is measured by using GIS technology.

In this case study, we conducted a scenario analysis through PMP model assuming a certain number of hubs, $\mathrm{P}$, to determine hub locations and covering stops in user template model. Assuming two to eight number of hubs, optimal hub location and its cluster are found in each scenario. The Risk Solver, add-on analysis tool used in Microsoft Excel platform, was used to implement the user template model [24]. The Risk Solver is widely used to optimization modelling due to its user-friendly interface, rapid modelling ability, and ease of use. The user template model will be used for further adjustment and decision-making for school bus management division. Figure 1 illustrates a screen captured for the optimal hub location decision in user template model for Region B.

Tables 1 and 2 show the results obtained for the hub location decision in Region $A$ in this case study. Table 1 summarizes the number of bus stops clustered and routed students resulting from various settings of the number of hubs. The average number of grouped bus stops per hub is decreased where the number of hubs is increased as we expected. On the other hand, the number of stops is more evenly distributed in case of three hubs with the lowest standard deviation. This fact implies that the route length in each hub sector would be more even so that planning and management activity is much easier in practice. The number of routed students means the actual number of students who travelled from their origin to the school passing through a nearby hub. In general, the larger number of route students in a certain hub region, the larger number of vehicles or frequencies is needed. Assuming the routing plan from hubs to a school in the future, a flatter number of routed students is beneficial and robust from the planning point of view. In case of three or five hubs, we obtained relatively less fluctuated demand among hubs in this study.

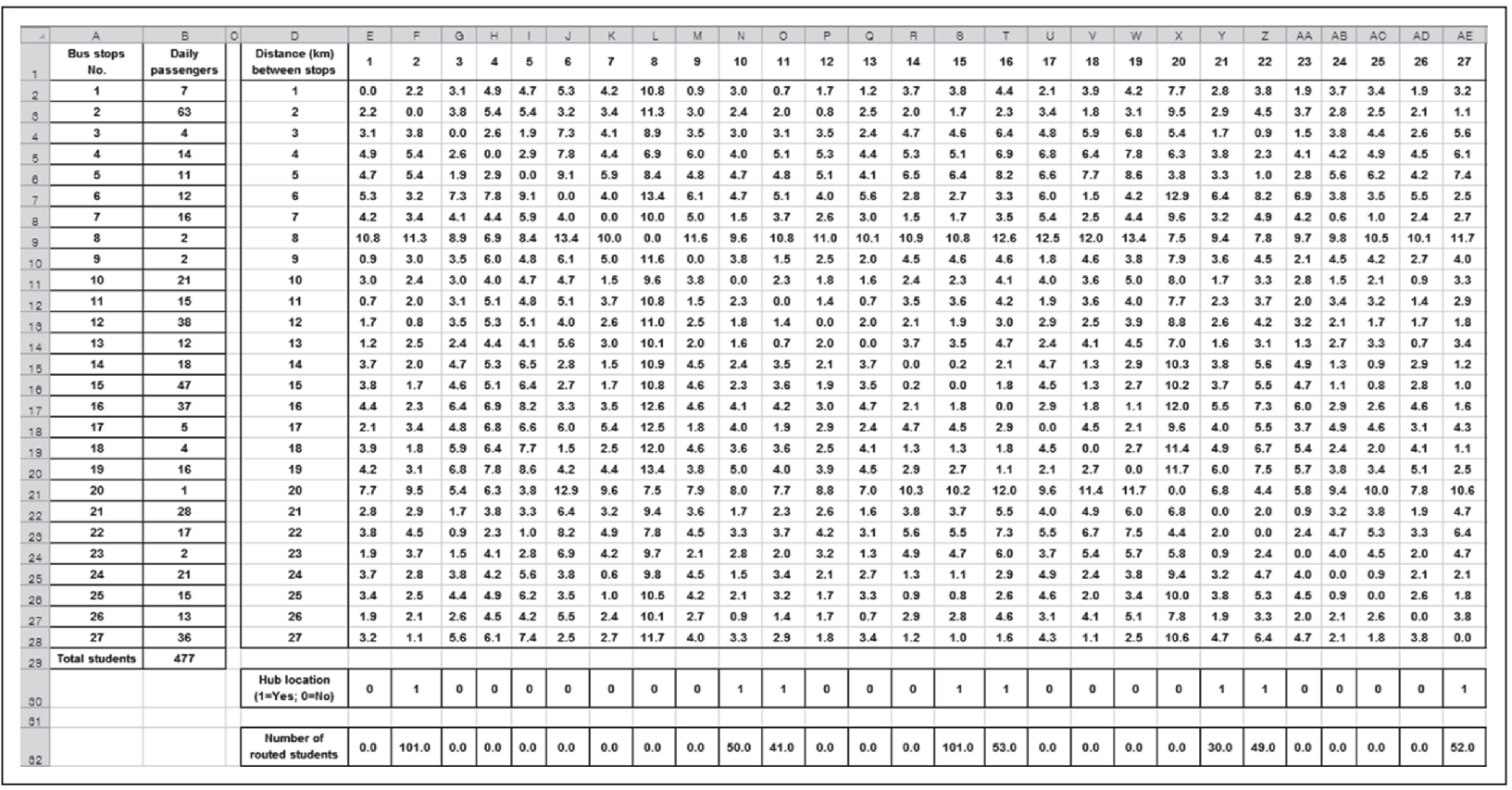

Figure 1 - User template model 
J. Kim, S. Soh: Designing Hub-and-Spoke School Bus Transportation Network: A Case Study of Wonkwang University

Table 1 - Number of bus stops and routed students in Region A

\begin{tabular}{||c|c|c|c|c||}
\hline \multirow{2}{*}{$\begin{array}{c}\text { Number } \\
\text { of hubs }\end{array}$} & \multicolumn{2}{|c|}{ Number of Bus stops } & \multicolumn{2}{c||}{ Number of Routed students } \\
\cline { 2 - 5 } & Mean & Stand. dev. & Mean & Stand. dev. \\
\hline \hline 2 & 21.50 & 9.19 & 959.50 & 331.63 \\
\hline 3 & 14.33 & 1.53 & 639.67 & 90.91 \\
\hline 4 & 10.75 & 4.35 & 479.75 & 175.78 \\
\hline 5 & 8.60 & 3.21 & 383.80 & 141.83 \\
\hline 6 & 7.17 & 3.97 & 319.83 & 119.60 \\
\hline 7 & 6.14 & 2.67 & 274.14 & 104.14 \\
\hline 8 & 5.38 & 2.07 & 239.88 & \\
\hline
\end{tabular}

Table 2 - Travel distance in Region A

\begin{tabular}{||c|c|c|c|c|c|c||}
\hline \multirow{2}{*}{$\begin{array}{c}\text { Number } \\
\text { of hubs }\end{array}$} & \multicolumn{2}{|c|}{ Demand-weighted travel distance } & \multicolumn{3}{c||}{ Travel distance/student } \\
\cline { 2 - 7 } & Total & Mean & Stand. dev. & Total & Mean & Stand. dev. \\
\hline \hline 2 & $4,742.50$ & 110.29 & 118.64 & 119.60 & 2.78 & 1.64 \\
\hline 3 & $3,666.80$ & 85.27 & 85.86 & 96.90 & 2.25 & 1.20 \\
\hline 4 & $3,127.20$ & 72.73 & 81.99 & 87.60 & 2.04 & 1.16 \\
\hline 5 & $2,687.40$ & 62.50 & 74.83 & 81.50 & 1.90 & 1.18 \\
\hline 6 & $2,297.60$ & 53.43 & 60.15 & 73.30 & 1.70 & 0.97 \\
\hline 7 & $1,977.00$ & 45.98 & 51.52 & 67.20 & 1.56 & 0.96 \\
\hline 8 & $1,658.80$ & 38.58 & 39.67 & 60.30 & 1.40 & 0.90 \\
\hline \hline
\end{tabular}

Table 2 shows the results of travel distance to students in Region A. In reality, the average travel distance among students who reside in widely dispersed areas should be fair. The travel distance per student among various hub regions is a good indicator to represent the level of fairness between students. The fairness issue should be considered as a key operational goal to avoid many complaints from the users and to achieve high quality of service. As indicated in Table 2 , the larger number of hubs is capable of increasing the level of fairness. However, too many sets of hub locations makes it difficult to establish an effective routing plan from hub to school. In addition, an excessive number of hubs would be a critical reason for unnecessarily long travel time from each hub to school while relatively short travel time can be accomplished inside each hub region. Figure 2 shows the final spatial distribution of hubs and spokes in Region B at the Wonkwang University.

As a summary, planning of hub location should consider various operational goals and level of service issues such as reducing overall cost, accomplishing a certain level of service, and other operational concerns. From the analysis above, establishing five hubs is expected to be appropriate in terms of the number of bus stops that is related to operational concerns and of number of routed students related to the quality of service. Locating more than five hubs leads route planning from hubs to school to be difficult due to excessive number of hubs, even though the travel time reaching a hub is shortened. Conversely, less than five hubs can offer high quality of service by providing di-

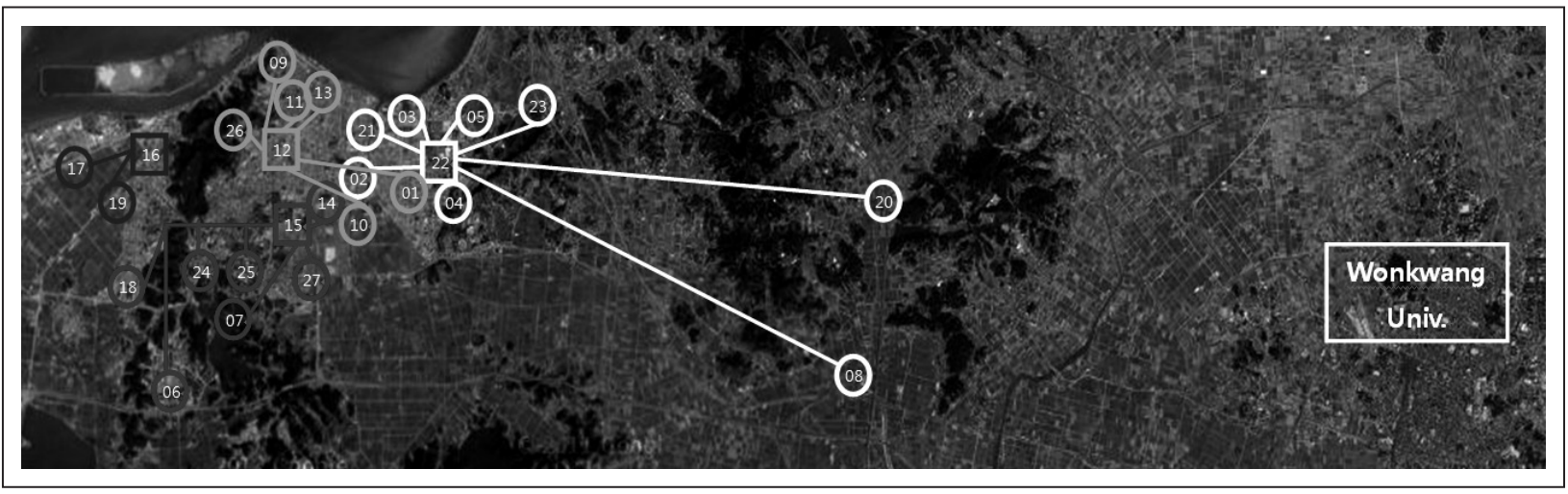

Figure 2 - Spatial distribution of hubs and spokes in Region B 
rect transportation service from fewer hubs. However, longer travel time from each stop to a hub within each hub sector would be the main reason to decrease the level of service and to make route planning between stops complicated. Conclusively, the optimal hub location decision in practice should be accomplished not only based on the simulation results but also on integrated hands-on experiences and expertise of school bus planners, dispatchers and drivers.

\section{CONCLUSION}

Hub-and-spoke network is a type of transportation network that manages hubs as collecting points of traffic or shipments from each spoke to the corresponding hubs. A hub-and-spoke network strategy is economically beneficial to provide lower transportation cost per user and more service frequencies to hub-to-hub routes. In this case study, a hub-and-spoke network strategy for school bus transportation network design simulation with various scenarios has been studied. The mathematical model of PMP assuming a certain number of hubs is utilized to design the underlying network structure. The objective of PMP applied here is to minimize the total demand-weighted distance that is a closely related goal to high quality of service. The PMP optimization model has been implemented to spreadsheet platform employing Excel add-on analysis tool. The implemented Excel template can be used for planners to make proper decisions by setting various operational scenarios in the future. From a variety of scenario analyses, we are able to identify operational characteristics to hub-and-spoke school bus network depending on the number of hubs.

The future managerial issues found through this case study are as follows. First, small number of hubs is favourable to effective hub-to-school route planning through a possible direct commuting service. However, too many routing options between stops in each hub sector make the planning tasks more challenging and also increase the travel time to reach designated hubs. Second, establishing too many hubs is advantageous to making travel time shorter to access hubs which are fairly beneficial to users. On the other hand, this fact would be a possible cause to longer travel time in hub-to-school routes and also to incur high operational costs from the planning point of view. Finally, from the lessons given by the simulation result, we found proper number of hubs satisfying the operational goals including the overall cost minimization and improving the service level in each study area. This result will be referred to managerial decisions for the school bus operating policy in the future. Even with identifying optimal number of hubs based on the analysis, other concerns such as hands-on experiences of planners or understanding practical operational constraints should be incorporated to make the decisions more effectively. The more detailed performance analysis will be conducted in the near future based on the key performance measures such as average travel time, seat availability ratios, and cost effectiveness.

\section{ACKNOWLEDGEMENT}

This paper was supported by the Wonkwang University in 2012. Dr. Jun-Hyuk Kim is the first author and Dr. SoonHu Soh is the corresponding author.

\section{Dr. 김준혁}

E-mail: junhyuk@koti.re.kr

한국교통연구원

경기도 고양시 일산서구 고양대로 $315,411-701$, 대한민

국

Dr. 소순후

E-mail: soonhu@wku.ac.kr

원광대학교 경영학부

전북 익산시 신용동 344-2, 570-749, 대한민국

\section{허브-스포크 방식의 스쿨버스 운행 네트워크 설계: 원광대학교 사례연구}

본 논문은 허브-스포크 방식의 스쿨버스 운행 네트워 크 설계문제에 관한 사례연구를 다룬다. 이 사례연구는 최 적 허브위치선정을 위하여 P-메디안 최적화 모델인 수리 모형을 이용한다. P-메디안 문제는 많은 이진변수와 제약 을 포함하는 조합최적화 문제이다. 이 모형에서 선택된 목 적은 운영적 제약들을 만족함과 동시에 총수송시간을 최 소화 하는 것이다. 향후 의사결정과정의 편리성을 높이기 위하여 스프레드시트 기반의 템플릿을 통한 시뮬레이션 모형을 구현한다. 개발된 모형은 스쿨버스 운행정책의 개 선방향을 구체화하는데 참고자료로 사용될 것이다.

허브-스포크 네트워크, 스쿨버스, P-메디안 모형, 사례연 구

\section{LITERATURE}

[1] Aykin, T.: The hub location and routing problem, European Journal of Operational Research, Vol. 83, No. 1, 1995, pp. 200-219

[2] Ernst, A. T., Krishnamoorthy, M.: Efficient algorithms for the uncapacitated single allocation p-hub median problem, Location Science, Vol. 4, No.3, 1996, pp. 139-154

[3] Elhedhli, S., Hu, F. X.: Hub-and-spoke network design with congestion, Computers and Operations Research, Vol. 32, No. 6, 2005, pp. 1615-1632

[4] Kim, J. H.: An Agent-based Model for Airline Evolution, Competition, and Airport Congestion, Ph.D. thesis, Dept. of Civil \& Environmental Engineering, Virginia Polytechnic Institute \& State University in Blacksburg, Virginia, U.S.A., 2005

[5] Campbell, J. F.: Integer programming formulations of discrete hub location problems, European Journal of Operational Research, Vol. 72, No. 2, 1994, pp. 387405

[6] Tuljak-Suban, D., Twrdy, E.: Decision Support for Optimal Repositioning of Containers in a Feeder System, 
PROMET - Traffic \& Transportation, Vol. 20, No. 2, 2008, pp. 71-77

[7] Shin, K. S., Kim, J. H., Kim, Y. K.: A Two-Leveled Multiobjective Symbiotic Evolutionary Algorithm for the Hub and Spoke Location Problem, Journal of Advanced Transportation, Vol. 43, No. 4, 2009, pp. 391-411

[8] Bodin, L. D., Berman, L.: Routing and scheduling of school buses by computer, Transportation Science, Vol. 13, No. 2, 1979, pp. 113-129

[9] Bowerman, R., Hall, B., Calamai, P.: A multi-objective optimization approach to urban school bus routing: formulation and solution method, Transportation Research Part A: Policy and Practice, Vol. 29, No. 2, 1995, pp. 107-123

[10] Braca, J., Bramel, J., Posner, B., Simchi-Levi, D.: A com puterized approach to the New York City school bus routing problem, IIE Transactions, Vol. 29, No. 8, 1997, pp. 693-702

[11] Li, L., Fu, Z.: The school bus routing problem: A case study, Journal of the Operational Research Society, Vol. 53, No. 5, 2002, pp. 552-558

[12] Angel, R. D., Caudle, W. L., Noonan, R., Whinston, A.: Computer-assisted school bus scheduling, Management Science, Vol. 18, No. 6, 1972, pp. 279-288

[13] Bookbinder, J. H., Edwards, S. H.: School-bus routing for program scheduling, Computers and Operations Research, Vol. 17, No. 1, 1990, pp. 79-94

[14] Park, J., Kim, B.: The school bus routing problem: A review, European Journal of Operational Research, Vol. 202, No. 2, 2010, pp. 311-319

[15] Melkote, S., Daskin, M. S.: Capacitated facility location/network design problems, European Journal of
Operational Research, Vol. 129, No. 3, 2001, pp. 481495

[16] Revelle, C. S., Laporte, G.: The plant location problem: New models and research prospects, Operations Research, Vol. 44, No. 6, 1996, pp. 864-874

[17] Ebery, J., Krishnamoorthy, M., Ernst, A., Boland, N.: The capacitated multiple allocation hub location problem: formulations and algorithms, European Journal of Operational Research, Vol. 120, No. 3, 2000, pp. 614631

[18] Beasley, J. E.: A note on solving large p-median problems, European Journal of Operational Research, Vol. 21, No.2, 1985, pp. 270-273

[19] Dai, Z., Cheung, T. Y.: A new heuristic approach for the p-median problem, Journal of Operational Research Society, Vol. 48, No. 9, 1997, pp. 950-960

[20] Alp, O., Erkut, E., Drezner, D.: An efficient genetic algorithm for the p-median problem, Annals of Operations Research, Vol. 122, No. 1-4, 2003, pp. 21-42

[21] Chaudhry, S. S., He, S., Chaudhry, P. E.: Solving a class of facility location problems using genetic algorithm, Expert Systems, Vol. 20, No. 2, 2003, pp. 86-91

[22] Topcuoglu, H., Corut, F., Ernis, M., Yilmaz, G.: Solving the uncapacitated hub location problem using genetic algorithms, Computers and Operations Research, Vol. 32, No. 4, 2005, pp. 967-984

[23] Mladenovic, N., Brimberg, J., Hansen, P., MorenoPerez, J. A.: The p-median problem: A survey of metaheuristic approaches, European Journal of Operational Research, Vol. 179, No. 3, 2007, pp. 927-939

[24] Frontline Systems Inc., Risk Solver Platform for Excel, 2010 (Available from: http://www.solver.com/platform/risk-solver-platform.htm) 